Indonesian Journal of Nutrition and Dietetics Vol. 6, Issue 1, 2018: 7-13
Available online at: http://ejournal.almaata.ac.id/index.php/IJND DOI : http://dx.doi.org/10.21927/ijnd.2018.6(1).7-13

\title{
Multiple micronutrients supplementation (sprinkles) increased energy and nutrient intake of children aged 1-3 years
}

\author{
Yulinda Kurniasari', Siti Madanijah², Mira Dewi ${ }^{2}$ \\ ${ }^{1}$ Department of Nutrition, Faculty of Health Sciences, Universitas Alma Ata \\ Jalan Brawijaya No. 99, Tamantirto, Yogyakarta 55183, Indonesia, \\ Telephone.(+62 274) 4342288 Fax. (+62 274) 4342269 \\ ${ }^{2}$ Department of Community Nutrition, Faculty of Human Ecology (FEMA), Bogor Agricultural University \\ Jalan Kamper Kampus IPB Darmaga, Bogor 16680, Indonesia, \\ Telephone. (+62 251) 8629227, Fax. (+62 251) 8629227 \\ ${ }^{*}$ Corresponding author: kurniasari.yulinda@gmail.com
}

\begin{abstract}
ABSTRAK
Latar belakang: Usia balita merupakan periode emas (golden periods) dalam proses tumbuh kembang sehingga asupan zat gizi makro dan zat gizi mikro sangat dibutuhkan. Taburia merupakan bubuk multivitamin dan multimineral yang dimaksudkan untuk memenuhi kebutuhan zat gizi mikro anak dan mengatasi permasalahan kekurangan gizi mikro.

Tujuan: Untuk menganalisis pengaruh pemberian Taburia terhadap perubahan asupan energi dan zat gizi anak usia 1-3 tahun.

Metode: Desain penelitian adalah quasi experimental study dengan pretest postest control group design, dilakukan pada bulan Januari-Juli 2012 di wilayah Puskesmas Banjar Serasan Kecamatan Pontianak Timur sebagai wilayah intervensi dan di wilayah Puskesmas Tambelan Sampit Kecamatan Pontianak Timur sebagai wilayah kontrol. Pengumpulan data dilakukan pada 85 anak, terdiri dari 45 sampel dalam kelompok intervensi dan 40 sampel dalam kelompok kontrol yang dipilih secara purposive sampling. Uji beda pada karakteristik dianalisis dengan chi-square. Uji beda rata-rata perubahan asupan energi dan zat gizi antara kelompok intervensi dan kelompok kontrol dengan uji independent samples t-test. Asupan energi dan zat gizi pretest dan post test dalam satu kelompok dianalisis menggunakan paired samples t-test.

Hasil: Hasil uji t-test terhadap rata-rata asupan energi dan zat gizi antara kedua kelompok menunjukkan adanya perbedaan secara bermakna, kecuali vitamin B12 $(p<0,05)$. Rata-rata asupan energi dan zat gizi pretest dan post test setelah dua bulan intervensi menunjukkan adanya peningkatan yang signifikan $(p<0,05)$.
\end{abstract}

Kesimpulan: Pemberian Taburia menghasilkan pengaruh positif berupa peningkatan rata-rata asupan energi dan zat gizi. Peningkatan asupan energi secara statistik menunjukkan ada perbedaan yang bermakna antara kedua kelompok.

KATA KUNCI: anak usia 1-3 tahun, zat gizi mikro, sprinkle, suplementasi, Taburia

\begin{abstract}
Background: Children under-five is the golden period in the process of child growth, therefore the macronutrient and micronutrient intake are needed. Taburia is a multiple micronutrients supplementation (sprinkles) that is intended to supply the multiple micronutrients needs of the child and resolve the micronutrient deficiencies problems of children.

Objectives: To analyze the effect of Taburia intervention on the energy and nutrient intake of children under three years old.

Methods: A quasi-experimental design was used to examine children's energy and nutrient intake at baseline, one month, and two months after the Taburia supplementation. The study was carried out from January-July 2012 at Community Health Centers Banjar Serasan as an intervention area and Community Health Centers of Tambelan Sampit as a control area. Data was collected on 85 children, consisting of 45 subjects of the intervention group and 40 subjects of the control group, selected by purposive sampling. Characteristic variables were analyzed by chi-square. Intake of energy and nutrients between the
\end{abstract}


intervention group and the control group were analyzed using independent samples t-test. The average of energy and nutrients intake between pre-test and post-test in one group were analyzed using paired samples t-test.

Results: Intake of energy and nutrients between the two groups showed significant differences, except for vitamin B12 $(p<0.05)$. Intake of energy and nutrients between pre-test and post-test after two months of intervention showed a significant improvement $(p<0.05)$.

Conclusion: The multiple micronutrients intervention has a positive impact on increasing energy and nutrients intake.

KEYWORDS: children, multiple micronutrient, sprinkle, supplementation, Taburia

\section{INTRODUCTION}

Linear growth of early childhood is considered a good growth marker, associated with shortterm morbidity and mortality, incidence of noncommunicable diseases in adulthood, declining learning ability, and low work productivity (1). The consequences of micronutrient deficiencies during childhood are associated with the risk of growth failure. Research results showed that micronutrients play an important role in achieving and maintaining optimal health at all stages of life.

Toddler age is a golden period in the process of growth and development, even under the age of two is a window of opportunity groups, so the intake of macro and micronutrients such as vitamins and minerals should be adequate (2). Data from national consumption surveys across Europe indicate the inadequate prevalence of micronutrient intake in the population subset, ie children, adolescents, women of childbearing age and older adults (3). The use of nutritional supplements had been effective in addressing inadequate micronutrient intake at the individual level (4). An economical potential solution is the fortification of complementary home meals with sprinkles powder, crushable nutritabs tablet, energydense food (108 kcal/day), or fat-based nutributter (5).

Taburia is a multivitamin and multimineral sprinkle that is intended to supply the micronutrients needs of the child and resolve the micronutrient deficiencies problems of children. Taburia is distributed among the Nutrition Improvement through Community Empowerment (NICE) program, which is one of the community empowerment projects by the government. Every infant, toddler, pregnant and lactating mothers receive health care and nutrition improvement includes promotive, preventive, curative and rehabilitative, including supplementation of micronutrients through Taburia (6).

The effect of micronutrient supplementation on appetite enhancement that saw from increased energy and nutrient intake has been shown in some previous studies $(7,8)$, but no similar studies had been done in Indonesia, including West Borneo. Based on these data, the author would like to investigate the effect of Taburia supplementation on the change of energy and nutrient intake of children aged 1-3 years in Banjar Serasan Community Health Centre as intervention area and Puskesmas Tambelan Sampit as a control area, Sub Pontianak Timur, West Borneo.

\section{MATERIALS AND METHODS}

A quasi-experimental study with pre- and posttest control group design was used to examine children's energy and nutrient intake at baseline, one month, and two months after the multiple micronutrients supplementation (sprinkles). In Indonesia, the National Institute for Health Research and Development (NIHRD) of the Ministry of Health $(\mathrm{MOH})$ developed a local sprinkle named "Taburia", currently (2017) being distributed across 3 of 34 provinces, and 64 of 514 districts. Taburia contains 14 micronutrients, including iron as ferrous fumarate $(10 \mathrm{mg})$, and its formulation is regulated by technical specifications of the $\mathrm{MOH}$ (amended in 2013) to fulfill the daily micronutrient needs of young children, i.e., at least $100 \%$ of the WHO/Food 
and Agriculture Organization of the United Nations (FAO) recommended nutrient intakes (RNIs) [9]. The composition of Taburia shown in Table 1.

This study was carried out at Puskesmas Banjar Serasan as the intervention area and Puskesmas Tambelan Sampit as the control area in the Pontianak Timur District, West Borneo during January-July 2012. Subjects were children aged 1-3 years selected by purposive sampling. A total of 96 children were selected consisting of 56 subjects from the intervention group and 40 subjects from the control group. Of these, 11 subjects from the intervention group were dropped out (unable to follow the study to completion) because the compliance rate was less than $80 \%$. At the end of

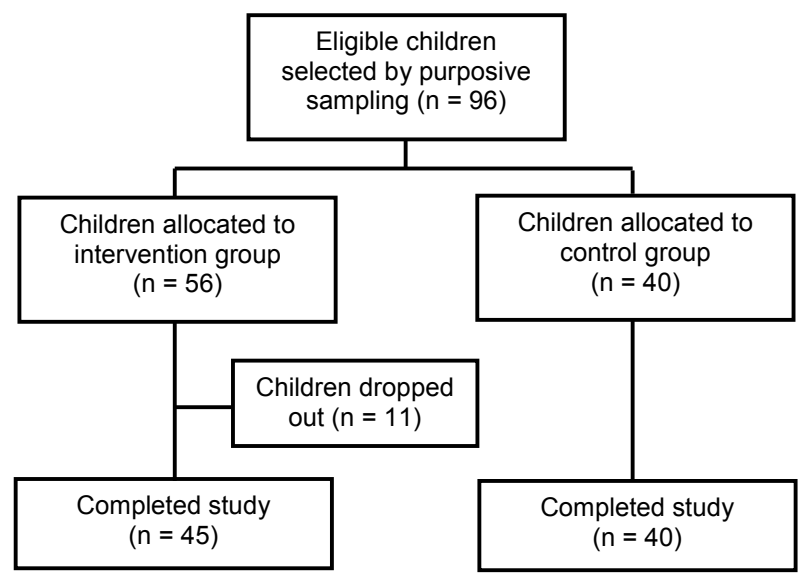

Figure 1. Trial profile

Tabel 1. Presence of, and percentage of the Recommended Dietary Allowances (RDA) provided by Taburia

\begin{tabular}{ccc}
\hline Nutrients & Amount per serving & \% RDA \\
\hline Vitamin A (mcg) & 417 & 104 \\
Vitamin D (mcg) & 5.0 & 33 \\
Vitamin E (mg) & 6.0 & 100 \\
Vitamin K (mcg) & 20.0 & 133 \\
Vitamin B1 (mg) & 0.5 & 83 \\
Vitamin B2 (mg) & 0.5 & 71 \\
Vitamin B3 (mg) & 5.0 & 83 \\
Vitamin B6 (mg) & 0.5 & 100 \\
Vitamin B12 (mcg) & 1.0 & 90 \\
Folic acid (mcg) & 150 & 94 \\
Vitamin C (mg) & 30 & 75 \\
Fe (mg) & 10 & 125 \\
lodium (mcg) & 50 & 42 \\
Zinc (mg) & 5.0 & 80 \\
\hline
\end{tabular}

the study, the number of toddlers observed was 85 subjects consisting of 45 subjects in the intervention group and 40 subjects in the control group. Intake of energy and nutrients include protein, vitamin $A$, vitamin $D$, vitamin $E$, vitamin $B$, vitamin $B 1$, vitamin B2, folic acid, vitamin C, iron, zinc and iodine are assessed using recall method $2 \times 24$ hours at the baseline, one month follow-up, and two months follow-up after the intervention.

Characteristic variables were analyzed by chi-square. Intake of energy and nutrients between the intervention group and the control group were analyzed using independent samples t-test. Energy and nutrients intake between pretest and posttest in one group were analyzed using paired samples t-test. This research used the $95 \%$ confidence level $(\alpha=0.05)$.

\section{RESULTS}

\section{Subject characteristics}

The effect of sprinkles on increases of energy and nutrient intake in this study also influenced by some variables that have the potential to interfere the results of the study. Factors that may affect the energy and nutrient intake of children that must be controlled before conducting the research shown in Table 2.

Most of the subjects in the intervention group were female $(57.8 \%)$, while the control group was mostly male $(60 \%)$. The age categories of subjects were between 23-36 months. The

Table 2. Characteristics of children, by group ${ }^{1}$

\begin{tabular}{lccccc}
\hline \multirow{2}{*}{ Variable } & \multicolumn{2}{c}{$\mathbf{I}(\mathbf{n = 4 5})$} & \multicolumn{2}{c}{$\mathbf{C ~ ( n = 4 0 )}$} & \multirow{2}{*}{$\boldsymbol{P}$} \\
\cline { 2 - 5 } & $\mathbf{n}$ & $\mathbf{\%}$ & $\mathbf{n}$ & $\mathbf{\%}$ & \\
\hline Sex & & & & & \\
$\quad$ Male & 19 & 42.2 & 24 & 60.0 & $0.130^{2}$ \\
$\quad$ Female & 26 & 57.8 & 16 & 40.0 & \\
Age (months) & & & & & \\
$\quad$ 12-23 & 20 & 44.4 & 18 & 45.0 & $1.000^{2}$ \\
$23-36$ & 25 & 55.6 & 22 & 55.0 & \\
Weight (kg) & $10.5 \pm 1.5$ & $10.3 \pm 1.7$ & $0.426^{3}$ \\
Height (cm) & $82.3 \pm 6.9$ & $83.9 \pm 8.1$ & $0.327^{3}$ \\
Nutritional status & $-0.87 \pm 0.84$ & $-1.14 \pm 0.95$ & $0.173^{3}$ \\
\hline 1 I, Intervention; C, Control & & & \\
2 Based on chi square & & & & \\
3 Based on t-test & & & &
\end{tabular}


mean of weight and height between the two groups showed no significant differences. The test result from all variables showed no statistically significant difference between the two groups, it could be concluded that the variables of subjects characteristics that identified have the potential to disrupt the results of this study have been controlled.

\section{Family characteristics}

The observed of family characteristics include parent education, parent employment, per capita income and household size presented in Table 3.

Both in the intervention and control group, parental education were mostly below the senior high school. The results showed that most mother's employment in both groups were unemployed. Most of the subject families categorized into upper-middleincome economic status. The most of household size in both groups was five and belonged to a moderate family based on Indonesian National Population and Family Planning Board category.

The test results of these variables showed no significant differences between the two groups. Based on these results, it can be concluded that the family characteristics variables did not have the potential to interfere with research results.

\section{Changes in energy and nutrient intake}

Energy and nutrient intake assessed at the baseline, one month follow-up, and two months follow-up after the intervention using recall method 2x24 hours shown in Table 4.

At baseline, the average of 11 types of nutrients intake did not differ between the intervention group and the control group. The other five types of vitamin $\mathrm{B} 1$, folic acid, vitamin $\mathrm{C}$, iron and zinc were statistically different between the intervention group and the control group.

The results showed that one month post intervention of sprinkles, the average energy and nutrient (vitamin $D$, vitamin $E$, vitamin $K$, vitamin B1, vitamin B2, vitamin B3, vitamin B6, folic acid, vitamin $C$, iron, zinc and iodine) intake of children increased significantly. Two months post intervention, the average energy and nutrient intake of children increased. The results showed a significant difference between the two groups, except vitamin B12.

\section{DISCUSSION}

The average of pre- and posttest energy and nutrients intake performed within two months

Table 3. Characteristics of the family, by group ${ }^{1}$

\begin{tabular}{|c|c|c|c|c|c|}
\hline \multirow{2}{*}{ Variable } & \multicolumn{2}{|c|}{$I(n=45)$} & \multicolumn{2}{|c|}{$C(n=40)$} & \multirow{2}{*}{$P^{2}$} \\
\hline & $\mathbf{n}$ & $\%$ & $\mathbf{n}$ & $\%$ & \\
\hline \multicolumn{6}{|l|}{ Father's education } \\
\hline Did not complete senior high school & 29 & 64.40 & 23 & 57.50 & \multirow[t]{2}{*}{0.66} \\
\hline Completed senior high school & 16 & 35.60 & 17 & 42.50 & \\
\hline \multicolumn{6}{|l|}{ Mother's education } \\
\hline Did not complete senior high school & 28 & 62.20 & 24 & 60 & \multirow[t]{2}{*}{1.00} \\
\hline Completed senior high school & 17 & 37.80 & 16 & 40 & \\
\hline \multicolumn{6}{|l|}{ Father's employment } \\
\hline Entrepreneur / employee & 31 & 68.90 & 19 & 47.50 & \multirow[t]{2}{*}{0.05} \\
\hline Fisherman / labor & 14 & 31.10 & 21 & 52.50 & \\
\hline \multicolumn{6}{|l|}{ Mother's employment } \\
\hline Employed & 5 & 11.10 & 12 & 30 & \multirow[t]{2}{*}{0.05} \\
\hline Unemployed & 40 & 88.90 & 28 & 70 & \\
\hline \multicolumn{6}{|l|}{ Per capita income } \\
\hline Lower-middle-income & 6 & 13.30 & 7 & 17.50 & \multirow[t]{2}{*}{0.76} \\
\hline Upper-middle-income & 39 & 86.70 & 33 & 82.50 & \\
\hline Household size & \multicolumn{2}{|c|}{$5 \pm 1.90$} & \multicolumn{2}{|c|}{$5 \pm 1.80$} & 0.16 \\
\hline
\end{tabular}


Table 4. The average of energy and nutrient intake per day at baseline, one month follow-up, two month follow-up

\begin{tabular}{lccccccccc}
\hline Energy and nutrient & \multicolumn{3}{c}{ Baseline } & \multicolumn{3}{c}{ 1-month follow-up } & \multicolumn{3}{c}{ 2-month follow-up } \\
\cline { 2 - 10 } intake & I & $\mathbf{C}$ & $\boldsymbol{P}$ & $\mathbf{I}$ & $\mathbf{C}$ & $\boldsymbol{P}$ & I & C & $\boldsymbol{P}$ \\
\hline Energy (kcal) & 749 & 710 & 0.280 & 806 & 741 & 0.053 & 876 & 775 & 0.003 \\
Protein (g) & 28.5 & 29.1 & 0.744 & 32.3 & 29.6 & 0.081 & 34.8 & 30.4 & 0.004 \\
Vitamin A (mcg) & 778.4 & 879.7 & 0.488 & 1042.4 & 791.0 & 0.053 & 1085.3 & 806.0 & 0.004 \\
Vitamin D (mcg) & 5.8 & 5.9 & 0.850 & 7.89 & 5.3 & 0.000 & 9.1 & 5.4 & 0.000 \\
Vitamin E (mg) & 4.2 & 3.7 & 0.124 & 6.4 & 3.5 & 0.000 & 7.3 & 3.6 & 0.000 \\
Vitamin K (mcg) & 0.8 & 0.7 & 0.569 & 8.5 & 0.6 & 0.000 & 10.7 & 0.6 & 0.000 \\
Vitamin B1 (mg) & 0.3 & 0.2 & 0.036 & 0.5 & 0.2 & 0.000 & 0.5 & 0.3 & 0.000 \\
Vitamin B2 (mg) & 0.6 & 0.6 & 0.506 & 0.9 & 0.6 & 0.000 & 0.9 & 0.6 & 0.000 \\
Vitamin B3 (mg) & 4.3 & 4.7 & 0.194 & 6.6 & 4.7 & 0.000 & 7.5 & 4.9 & 0.000 \\
Vitamin B6 (mg) & 0.4 & 0.4 & 0.350 & 0.6 & 0.4 & 0.000 & 0.7 & 0.4 & 0.000 \\
Vitamin B12 (mcg) & 1.5 & 2.3 & 0.203 & 2.4 & 1.6 & 0.172 & 2.4 & 1.7 & 0.056 \\
Folic acid (mcg) & 66.9 & 85.6 & 0.022 & 121.2 & 77.3 & 0.000 & 135.5 & 77.7 & 0.000 \\
Vitamin C (mg) & 25.4 & 13.6 & 0.001 & 36.8 & 12.9 & 0.000 & 40.3 & 12.5 & 0.000 \\
Fe (mg) & 5.8 & 4.3 & 0.002 & 9.7 & 4.2 & 0.000 & 11.1 & 4.2 & 0.000 \\
Zinc (mg) & 3.4 & 2.8 & 0.009 & 5.5 & 2.8 & 0.000 & 6.2 & 2.9 & 0.000 \\
lodium (mcg) & 0.1 & 0.1 & 0.569 & 17.6 & 0.1 & 0.000 & 22.6 & 0.1 & 0.000 \\
\hline
\end{tabular}

*I, Intervention; C, Control

$\mathrm{P}$ : Based on t-test

Table 5. The average of energy and nutrient intake at baseline and post-intervention, by group ${ }^{1}$

\begin{tabular}{|c|c|c|c|c|c|c|}
\hline \multirow[b]{2}{*}{$\begin{array}{c}\text { Energy and } \\
\text { nutrient intake }\end{array}$} & \multicolumn{2}{|c|}{$I(n=45)$} & \multicolumn{4}{|c|}{$C(n=40)$} \\
\hline & Baseline & $\begin{array}{c}\text { Post- } \\
\text { intervention }\end{array}$ & $P^{2}$ & Baseline & $\begin{array}{l}\text { Post- } \\
\text { intervention }\end{array}$ & $P^{2}$ \\
\hline Energy (kcal) & $749 \pm 152$ & $876 \pm 140$ & 0.0000 & $710 \pm 179$ & $775 \pm 160.6$ & 0.0000 \\
\hline Protein (g) & $28.5 \pm 7.2$ & $34.8 \pm 6.6$ & 0.0000 & $29.0 \pm 8.9$ & $30.4 \pm 7.2$ & 0.1439 \\
\hline Vitamin A (mcg) & $774.4 \pm 192.9$ & $895.3 \pm 393.8$ & 0.0000 & $879.7 \pm 898.1$ & $806.0 \pm 484.2$ & 0.5401 \\
\hline Vitamin D (mcg) & $5.8 \pm 2.4$ & $6.6 \pm 2.6$ & 0.0000 & $5.9 \pm 3.1$ & $5.4 \pm 2.7$ & 0.0531 \\
\hline Vitamin E (mg) & $4.2 \pm 1.3$ & $4.6 \pm 1.3$ & 0.0000 & $3.7 \pm 1.5$ & $3.6 \pm 1.4$ & 0.1344 \\
\hline Vitamin K (mcg) & $0.8 \pm 1.0$ & $1.1 \pm 1.3$ & 0.0000 & $0.7 \pm 1.2$ & $0.6 \pm 1.4$ & 0.4738 \\
\hline Vitamin B1 (mg) & $0.3 \pm 0.9$ & $0.4 \pm 0.1$ & 0.0000 & $0.2 \pm 0.9$ & $0.3 \pm 0.7$ & 0.2099 \\
\hline Vitamin B2 (mg) & $0.6 \pm 0.2$ & $0.7 \pm 0.2$ & 0.0000 & $0.6 \pm 0.3$ & $0.6 \pm 0.2$ & 0.8690 \\
\hline Vitamin B3 (mg) & $4.3 \pm 1.4$ & $5.3 \pm 1.6$ & 0.0000 & $4.7 \pm 1.8$ & $4.9 \pm 1.6$ & 0.2322 \\
\hline Vitamin B6 (mg) & $0.4 \pm 0.1$ & $0.5 \pm 0.1$ & 0.0000 & $0.4 \pm 0.1$ & $0.4 \pm 0.2$ & 0.0997 \\
\hline Vitamin B12 (mcg) & $1.5 \pm 0.5$ & $2.0 \pm 1.7$ & 0.0012 & $2.3 \pm 3.8$ & $1.7 \pm 1.8$ & 0.2707 \\
\hline Folic acid (mcg) & $66.9 \pm 20.9$ & $78.3 \pm 24.7$ & 0.0000 & $85.6 \pm 48.9$ & $77.7 \pm 30.4$ & 0.2219 \\
\hline Vitamin C (mg) & $25.4 \pm 16.5$ & $24.6 \pm 14.7$ & 0.0000 & $13.6 \pm 14.5$ & $12.5 \pm 11.8$ & 0.3560 \\
\hline $\mathrm{Fe}(\mathrm{mg})$ & $5.8 \pm 2.3$ & $6.3 \pm 2.2$ & 0.0000 & $4.3 \pm 2.0$ & $4.3 \pm 2.1$ & 0.6027 \\
\hline Zinc (mg) & $3.4 \pm 1.0$ & $3.9 \pm 1.0$ & 0.0000 & $2.8 \pm 0.9$ & $2.9 \pm 0.9$ & 0.0741 \\
\hline Iodium (mcg) & $0.1 \pm 0.1$ & $0.1 \pm 0.1$ & 0.0000 & $0.1 \pm 0.1$ & $0.1 \pm 0.1$ & 0.4738 \\
\hline
\end{tabular}

${ }^{1}$ I, Intervention; C, Control

2 Based on t-test

after multiple micronutrients supplementation (sprinkles) showed a significant increase for energy and nutrients intake including protein, vitamin $A$, vitamin $D$, vitamin $E$, vitamin $K$, vitamin $B 1$, vitamin B2, vitamin B3, vitamin B6, vitamin
B12, folic acid, vitamin C, iron, zinc and iodine. This situation provides the same information with previous research results, showing that there was a significant increase in the mean of energy, protein, vitamin $A$, vitamin $B 1$, vitamin $B 2$, vitamin B3, vitamin 
B6, vitamin B12, vitamin D, folic acid, vitamins C, vitamin $\mathrm{E}$, iron, and zinc intake (10).

Sprinkles is expected to solve problems that often occur in children such as low intake of food. Changes in carbohydrates, fats and proteins into cellular energy in the form of ATP require several micronutrients as coenzymes and cofactors of enzymatic reactions, as structural components of enzymes and mitochondrial cytochrome, and as carriers of electrons and protons active respiratory chains that produce ATP (11). Multiple micronutrients supplementation can optimize the metabolism of nutrients, especially energy and protein caused by the compliance of micronutrient needs and the synergistic effect between nutrients on absorption and in metabolic processes. In Sprinkle, there were some micronutrients that can help increase appetite which were also increase children's daily calorie intake, such as vitamin $B$, vitamin $A$, iron and zinc.

Vitamin B1 serves as a cofactor for several enzymes involved in energy metabolism (12). Vitamin B2 plays an important role in cell metabolism, a precursor of the coenzyme flavin mono nucleotide (FMN) and flavin adenine dinucleotide (FAD), which acts as a hydrogen carrier in various biological redox reactions (13), Vitamin B12 acts as a key nutrient associated with one-carbon metabolic pathway with metabolic substrate, synthesis and stability of nucleic acids and DNA methylation that regulate gene expression (14). Vitamin A plays a role in the formation of red blood cells, vitamin A deficiency can cause appetite deficiency because of changes in jonjot taste on the tongue. Vitamin $\mathrm{C}$ helps the absorption of calcium, iron, reverses the effects of dietary inhibitors and is one of the most powerful promoters in the absorption of non-heme iron (15). Iron-folic acid (IFA) supplementation has been shown to improved appetite and increased food intake (16). A previous study identified that the iron supplementation-associated increase in appetite (17). Zinc supplementation improves appetite and weight in significant number of children with poor appetite and growth failure (18)

Sprinkles does not change the children's eating habits. Children can eat as usual without being disturbed even though the way of giving is sown on food. This indicates that sprinkles is tasteless, flavorful, and does not change the form of food. These results reinforce the claim that many of sprinkles advantages will not change the daily eating habits of the toddler, does not change the taste, flavor, or texture of toddler's food (19).

\section{CONCLUSION AND RECOMMENDATIONS}

The results showed that the sprinkles gave a positive effect of increasing energy and nutrients intake. Statistical results on energy and nutrient intake between the two groups showed a significant difference between the intervention and the control group after two months supplementation of sprinkles, except for vitamin B12.

Policy implementation for solving micronutrient deficiencies problem must be firmly rooted in a food-based approach rather than a drug-based approach. Nutrition intervention strategies that can be implemented include food diversification, supplemetation, nutrition education and staple food fortification. Considering the benefits in increasing the energy and nutrient intake of children, sprinkles supplements are recommended in all areas, not limited to NICE areas.

\section{REFERENCES}

1. McDonald CM, Manji KP, Kupka R, Bellinger $D C$, Spiegelman D, Kisenge R, Msamanga $G$, Fawzi WW, Duggan CP. Stunting and wasting are associated with poorer psychomotor and mental development in HIV-exposed Tanzanian infants. J. Nutr. 2013 Feb 1;143(2):204-14.

2. Soekirman. Sehat dan Bugar Berkat Gizi Seimbang. Jakarta: Kompas Gramedia; 2011.

3. Hennessy Á, Walton J, Flynn A. The impact of voluntary food fortification on micronutrient intakes and status in European countries: a review. Proc Nutr Soc. 2013 Nov 1;72(04):433-40.

4. Murphy SP, White KK, Park SY, Sharma S. Multivitamin-multimineral supplements' effect on total nutrient intake. Am J Clin Nutr. 2007 Jan 1;85(1):280S-4S.

5. Adu-Afarwuah S, Lartey A, Brown KH, Zlotkin S, Briend A, Dewey KG. Randomized comparison 
of 3 types of micronutrient supplements for home fortification of complementary foods in Ghana: effects on growth and motor development. Am J Clin Nutr . 2007 Aug 1;86(2):412-20.

6. Department of Health. Selayang Pandang NICE, Program Perbaikan Gizi Melalui Pemberdayaan Masyarakat. Jakarta: Ministry of Health Republic of Indonesia; 2008.

7. Adu-Afarwuah $\mathrm{S}$, Lartey $\mathrm{A}$, Brown $\mathrm{KH}$, Zlotkin $S$, Briend A, Dewey KG. Home fortification of complementary foods with micronutrient supplements is well accepted and has positive effects on infant iron status in Ghana. Am J Clin Nutr. 2008 Apr 1;87(4):929-38.

8. Karim F, Choudhury N, Pasha A, Hasan K, Hyder SMZ, Zlotkin SH. Reaching Sprinkles to millions: social marketing strategy for combating childhood iron deficiency anemia. BRAC 2006 May; 27: 45-46

9. Sutrisna A, Vossenaar M, Izwardy D, Tumilowicz A. Sensory Evaluation of Foods with Added Micronutrient Powder (MNP) "Taburia" to Assess Acceptability among Children Aged 6-24 Months and Their Caregivers in Indonesia. Nutrients. 2017; (9):979

10. Mursalim, Juffrie M, Mulyani NS. Effect fortified multi micronutrient to growth of under fives of 6-59 month from poor communities. IJCN. 2011 Okt;8(2): 69-80.

11. Huskisson E, Maggini S, Ruf M. The Role of Vitamins and Minerals in Energy Metabolism and Well-Being. J Int Med Res. 2007;35:277-289.
12. Fattal-Valevski A. Thiamine (vitamin B1). J. Evid. Based Complementary Altern. Med. 2011 Jan 1;16(1):12-20.

13. LeBlanc JG, Milani C, de Giori GS, Sesma F, Van Sinderen D, Ventura M. Bacteria as vitamin suppliers to their host: a gut microbiota perspective. Curr Opin Biotechnol. 2013 Apr 30;24(2):160-8.

14. Rush EC, Katre P, Yajnik CS. Vitamin B12: one carbon metabolism, fetal growth and programming for chronic disease. Eur $\mathrm{J}$ Clin Nutr. 2014 Jan 1;68(1):2-7.

15. Kaur S, Sangha JK. Effect of Iron Supplementation Along with Vitamin $C$ and Nutrition Counseling on the Anaemic Status of Adolescent Girls. Int. J Adv Health Sci. 2016;6(5):279-87.

16. Kanani SJ, Poojara RH. Supplementation with iron and folic acid enhances growth in adolescent Indian girls. ASN. J. Nutr. 2000 Feb; 130(2): 452S-455S

17. Andrews NC. Hungry irony. J Clin Invest. 2015;125(9):3422-3423

18. Shakur MS, Bano N, Malek MA, Kundu SK, Ahmed AU. Effect of zinc supplementation on appetite, growth \& body composition in children suffering from non-specific etiology of feeding refusal with failure to thrive. The ORION. 2009 Jan; 32(1): 612-615

19. Sopiyandi, Juffrie M, Susetyowati. Sprinkle (Taburia) supplementation influences the duration and frequency of acute diarrhea in children. IJCN. 2013 Jan;9(3): 117-23. 